\title{
Marka Özgünlüğünün Marka Güveni Üzerindeki Etkisi: Cep Telefonu Markaları Üzerine Bir Araştırma

\author{
(Effect of Brand Authenticity on Brand Trust: A Research on Mobile Phones)
}

\author{
A. Buğra HAMŞIOĞLU (iD a İ. Kutluhan PAPATYA (iD b \\ a Burdur Mehmet Akif Ersoy Üniversitesi, İktisadi ve İdari Bilimler Fakültesi, Burdur, Türkiye, abhamsioglu@mehmetakif.edu.tr \\ b Burdur Mehmet Akif Ersoy Üniversitesi, Sosyal Bilimler Enstitüsü, İşletme, Yüksek Lisans Öğrencisi, Burdur, Türkiye, \\ kpapatya@gmail.com
}

\begin{tabular}{|c|c|}
\hline MAKALE BİLGİSİ & ÖZET \\
\hline Anahtar Kelimeler: & Amaç - Bu çalışmanın amacı, tüketicilerin kullandıkları cep telefonu markalarını dikkate alarak marka \\
\hline Marka Özgünlügüü & ğünün marka güveni üzerindeki olası etkilerini belirlemeye yöneliktir. \\
\hline Marka Güveni & Yöntem - Çalışma Mayıs-Haziran 2021 de tüketicilere çevrimiçi anketle veri toplama yöntemi \\
\hline Cep Telefonu Markaları & $\begin{array}{l}\text { kullanılmış olup } 500 \text { anket elde edilmiş ancak hatalı ve eksik } 30 \text { anket tasnif dışı bırakılarak toplamda } \\
470 \text { anket üzerinden sonuçlar değerlendirilmiştir. Çalışmada kolayda örnekleme yöntemi }\end{array}$ \\
\hline Gönderilme Tarihi 12 Haziran & kullanılmıştır. Çalışmanın analizinde kısmi en küçük kareler yöntemi ile yapısal model test edilmiştir. \\
\hline 2021 & Bulgular - Elde edilen sonuçlara göre, marka özgünlüğünün marka güveni üzerinde doğrudan ve \\
\hline $\begin{array}{l}\text { Revizyon Tarihi } 1 \text { Eylül } 2021 \\
\text { Kabul Tarihi } 10 \text { Evlül } 2021\end{array}$ & pozitif bir etkisinin olduğu tespit edilmiştir. Ayrıca çalışmada marka özgünlüğü boyutlarının da ayrı \\
\hline Kabul Tarihi 10 Eylül 2021 & $\begin{array}{l}\text { ayrı marka güveni üzerindeki olası etkileri de test edilmiştir. Elde edilen sonuçlara göre marka } \\
\text { özgünlüğü boyutları (süreklilik, orijinallik, doğallık ve güvenilirlik) marka güveni üzerinde doğrudan } \\
\text { ve pozitif etkilerinin olduğu görülmüș ve oluşturulan arştırma hipotezleri kabul edilmiștir. }\end{array}$ \\
\hline
\end{tabular}

Makale Kategorisi:

Araştırma Makalesi

Tartışma - Tüketicilere yönelik olarak kullandıkları cep telefonu markası bağlamında marka özgünlüğü ve marka güveni incelenmiş olup sonuçlar tartışılmıştır.

\begin{tabular}{ll}
\hline ARTICLE INFO & ABSTRACT \\
\hline $\begin{array}{l}\text { Keywords: } \\
\text { Brand Authenticity } \\
\text { Brand Trust }\end{array}$ & $\begin{array}{l}\text { Purpose - This study aims to determine the probable effects of brand authenticity on brand trust } \\
\text { considering the brands of mobile phones used by the consumers. } \\
\text { Mobile Phone Brands }\end{array}$ \\
$\begin{array}{l}\text { Design/methodology/approach - In the study, the method of data collection through online survey } \\
\text { conducted on May-June 2021 for consumers has been used and 500 surveys have been submitted, } \\
\text { however, 30 surveys with mistakes or missing parts have been taken out of the classification and the } \\
\text { results have been assessed on 470 surveys in total. Convenience sampling method has been used in the } \\
\text { study. Structural model has been tested by partial least squares method in the analysis of the study. }\end{array}$ \\
$\begin{array}{l}\text { Received 12 June 2021 } \\
\text { Revised 1 September 2021 }\end{array}$ \\
$\begin{array}{l}\text { Findings - It has been detected in line with the results obtained that brand authenticity has a direct } \\
\text { and positive effect on brand trust. In addition, probable effects of brand authenticity dimensions on } \\
\text { brand trust have been tested individually. In line with the results, it has been observed that brand } \\
\text { authenticity dimensions (continuity, originality, naturalness and reliability) have direct and positive } \\
\text { effects on brand trust and the research hypotheses have been accepted. }\end{array}$
\end{tabular}

Research Article

Discussions - Brand authenticity and brand trust have been studied in the context of mobile phone brands used by the consumers and the results have been discussed. 


\section{Giriş}

Son yıllarda, markaların etik olmayan davranışları nedeniyle ön plana çıktığı ve marka güveninin azalmasına neden olduğu görülmektedir. Eggers vd., (2013) yılında yaptıkları çalışmada bunu kurumsal uyumsuzluğa bağlamışlardır. Markaların eylemleri, ilettikleri vaat ve değerlerden farklı olduğunda güvensizlik baş göstermektedir. Tüketiciler kendilerine sunulan bilgilere güvenemiyorlar ve sonuç olarak dürüst ve güvenilir markalara talep artmaktadır (Burnett ve Hutton, 2007). Marka güvenini oluşturmak için bir markanın hem iyi niyeti hem de sağlam yetenekleri olmalıdır (Delgado-Ballester ve Luis Munuera- Alemán, 2001; DelgadoBallester, 2004). Bu marka güveni tanımı, niyetlerini erdemli kurumsal değerler ve marka vaatlerini yerine getirme yetenekleri aracılı̆̆ıly gösteren özgün markaları yansıtmaktadır (Schallehn vd., 2014; Morhart, vd., 2015).

Guevremont ve Grohmann (2017) tarafından yapılan bir araştırmada, bir skandal durumunda tüketicilerin özgün olarak algılanan bir markaya daha fazla hoşgörü gösterdiğini ortaya koymuştur. Marka özgünlügünün marka güveni üzerinde olumlu bir etkisinin olduğu düşünülmektedir (Beverland, 2005a; Gilmore ve Pine, 2007; Molleda ve Jain, 2013). Bununla birlikte, marka özgünlügünün yapısı oldukça karmaşıktır ve kavramsallaştırılmasında bir uzlaşı sağlanamamaktadır (Beverland, 2005a; 2005b; Bruhn vd., 2012;Pace, 2015). Yazın boyunca özgünlük defalarca "hakiki, gerçek ve doğru" olarak tanımlanmaktadır (Beverland ve Farrelly, 2010).

Tüketiciler, neyin hakiki, içten, gerçek ve doğru olduğuna dair kendi anlayışlarına göre marka özgünlüğünün anlamını birlikte yaratırlar (Beverland ve Farrelly, 2010; Pace, 2015). Tüketici perspektifinden bakıldığında, özgün markalar daha az özgün olanlara kıyasla daha fazla kişisel değer sunmaktadır (Napoli vd., 2016). Markalar iletişim karmaşasında kendilerini farklılaştırmanın yeni yollarını aramaktadırlar (Alexander, 2009). Marka yöneticileri, neredeyse tüm mal ve hizmetlerin uzun zamandır meta haline geldiği gerçeğiyle yüzleşmektedir (Gilmore ve Pine, 2007).

Gilmore ve Pine (2007:5) de özgünlüğü, kalitenin maliyeti aştığı ve maliyetin elde edilebilirliği aştığı gibi, hakim kriter olarak kaliteyi de geride bırakmıştır. Markalar sadece performansa değil, bir işletme olarak neyi temsil ettiklerine odaklanarak müşteriyle kurdukları bağı güçlendirmeleri gerekmektedir (Burnett ve Hutton, 2007). Özgün markalar, kurumsal değerlerini uygulama ve eylemlerinin merkezine koymaktadır. Markalara insan benzeri nitelikler atfetmenin (marka antropomorfizmi) özgünlük algısını ve tüketicinin markaların içsel değerlerini tanıma yeteneğini geliştirdiği bulunmuştur (Eggers vd., 2013; Morhart vd., 2015). Endüstri öncesi değerlerin yeniden doğuşundan dolayı, tüketiciler insana benzeyen markalara giderek daha fazla düşkün hale gelmektedir (Brown, 2010; Malone ve Fiske, 2013).

Marka özgünlüğü konusunda sürekli bir araştırma olsa da, marka özgünlüğünün marka güveni üzerindeki etkisini ölçen çalışmalar henüz yeterli düzeyde değildir. Bu çalışma bu alandaki araştırma boşluğunu dolduracağı düşünülmektedir. Bu çalışmanın amacı marka özgünlüğünün marka güveni üzerindeki etkisini belirlemektir.

\section{Literatür Taraması}

Marka özgünlüğü, sürekli olarak marka güveniyle ilişkilendirilmiştir (Hon ve Grunig, 1999; Eggers vd., 2013; Napoli, vd., 2014; Schallehn vd., 2014). Temelde, özgün olan markalar sözlerini yerine getirmede kararlıdır ve tüketiciler söz verildiği gibi performans gösteren markalara güvenirler. Bugünün tüketici şüpheciliğinde güven düşüştedir ve özgünlük ise bunun tam bir panzehiridir (Bruhn vd., 2012; Eggers vd., 2013; Napoli vd., 2014; Morhart vd., 2015;).

\subsection{Marka Özgünlüğünün Boyutları}

Marka özgünlüğünün temel boyutları, bireysellik, orijinallik ve doğallıttır (Bruhn vd., 2012; Schallehn vd., 2014; Akbar ve Wymer, 2016), inanılırlık ve güvenilirlik (Bruhn vd., 2012; Morhart vd., 2015), tutarlılık (Eggers vd., 2013; Schallehn vd., 2014), süreklilik (Bruhn vd., 2012; Morhart vd., 2015) ve bütünlük ve sembolizm (Morhart vd., 2015). Marka özgünlüğü, herhangi bir köken, özgünlük ve benzersizlik görünümü aracılığıyla aktarılmaktadır (Vann, 2006). Algılanan özgünlük, markanın benzersiz olup olmadığının bir değerlendirmesi olarak tanımlanmaktadır (Bruhn vd., 2012). Benzer şekilde, bireysellik benzersiz bir şekilde tanımlanır ve markanın sözünü yerine getirir (Schallehn vd., 2014). Marka özgünlüğünde orijinallik ve bireysellik aynı 


\section{A. B. Hamşığlu - İ. K. Papatya 13/3 (2021) 2042-2055}

madalyonun iki yüzüdür (Bruhn vd., 2012:568) ayrıca doğallığı, içtenlik ve samimiyetin bir göstergesi olarak tanımlanmıştır. Özgün, işletmeler gerçek benliklerine göre hareket eder (Shen ve Kim, 2012). Doğal olmak orijinal olarak algılanmaktadır. Bu nedenle, bireysellik, orijinallik ve doğallığın boyutları markayı markalaşma ve markayı gerçek bir bağlam içine yerleştirmeye yönelik yeni bir yaklaşımla rakiplerinden farklılaştırarak markayı tanımlamaktadır (Portal vd., 2019).

Marka özgünlüğünün tüm boyutlarından süreklilik ve tutarlılık en sık tartışılandır. Süreklilik, bir markanın zamansızlığını ve trendlerini geride bırakma yeteneğini ifade eder. Süreklilik sunan bir marka, uzun vadede takip ettiği net bir kavrama ve vizyona sahiptir ve marka nitelikleri zamanla sabit kalmaktadır (Bruhn vd., 2012; Eggers vd., 2013; Schallen vd., 2014; Morhart vd., 2015). Tutarlılık, geleneksel olarak bir pazarlama karışımının her bir öğesi markanın daha büyük niyetlerini yansıttığı zaman ulaşılan durum olarak tanımlanmıştır (Portal vd., 2019). İletişim ve müşteri deneyimleri işletmenin kimliği, vizyonu ve değerleri ile tutarlı olduğunda tutarlılık hissedilmektedir (Eggers vd., 2013; Schallehn vd., 2014; Portal vd., 2019).

Süreklilik ve tutarlılık, marka inanılırlı̆̆ına ve güvenilirliğine yol açmaktadır. Özgün markalar, yüksek düzeyde inanılırlık ve güvenilirlikle ilişkilendirilir. Marka vaadini tekrar tekrar yerine getirmek için markanın değerleri, uygulama ve eylemlerinin ayrılmaz bir parçası olmalıdır. Kısacası, bir marka sözlerini yerine getirirse hem inanılır hem de güvenilirdir (Molleda, 2010; Bruhn vd., 2012; Eggers, vd., 2013; Molleda ve Jain, 2013; Morhart vd., 2015). Morhart vd., (2015) marka özgünlügünün boyutları olarak hem bütünlügü hem de sembolizmi dahil etmiştir. Özgün bir markanın erdemli değerleri vardır ve müşterilerine gerçekten değer verir. Dürüstlük, tutarlı ve adil davranış yoluyla deneyimlenir (Shen ve Kim, 2012; Morhart, 2015). Markanın erdemli niyetlerine yansır ve ahlaki saflığını ifade eder. Markanın tüketiciye değer katan bir samimiyet havasına sahip olması sembolizmdir (Beverland, 2005a). Markanın, müşteriler arasında gerçekten yankı uyandıran ve onlar için kişisel anlam katarak öz kimliklerinin inşasına katkıda bulunan niteliklere sahip olmasi gerekir (Morhart, vd., 2015; Portal vd., 2019).

\subsection{Marka Güveni}

Güven üzerine yapılan araştırmalar kapsamlıdır ve oldukça karmaşık ve gizli yapısı nedeniyle bu yapıyı tanımlamanın zorluklarını ortaya çıkarmıştır (Hobbs ve Goddard, 2015). Marka güveni teorisinin çoğu sosyoloji, psikoloji ve ekonomi alanlarına dayanmaktadır (Rousseau, vd.,1998;Delgado-Ballester ve Luis Munuera-Alemán 2001). Bu araştırmalar daha sonra pazarlama ve markalaşmada kullanılmak üzere uyarlanmıştır (Dowell, vd., 2013). Rousseau vd., (1998) güveni, bir başkasının niyet ve davranışlarına ilişkin olumlu beklentiler temelinde savunmasızlığı kabul etme isteği olarak tanımlamıştır. Morgan ve Hunt (1994) güveni, birinin diğerinin güvenilirliği ve bütünlügüne olan olumlu inancından kaynaklanmış olarak görmüşlerdir.

McAllister (1995) iki tür güven belirlemiştir; duygusal veya sıcak güven (birinin diğerinin en iyi çıkarlarına sahip olduğu zaman) ve rasyonel veya bilişsel güven (birinin belirli bir görevi yerine getirebileceğine inandığ1 zaman). Bu tanımlar, güvenin iki önemli yönünden bahsetmektedir; duygusal (niyet ve bütünlük) ve işlevsel (davranış ve güvenilirlik). Sosyolojide güven, geniş kategoriler halinde düzenlenmiştir; yani kurumsal güven (düzenleyici kurumlara güven), genelleştirilmiş güven (başkalarına güven), hesaplayıcı güven (rasyonel değerlendirmeye dayalı güven) ve ilişkisel güven (zaman içinde ve etkileşim yoluyla elde edilen güven) (Hobbs ve Goddard, 2015; Portal vd., 2019). Marka güveni, doğrudan deneyimler yoluyla zamanla gelişir ve bir ilişki bağlamında ortaya çıkar. Bu nedenle, ilişkisel güven ile daha yakından ilişkilendirilebilir (Chaudhuri ve Holbrook, 2001; Delgado-Ballester ve Luis Munuera-Alemán, 2001).

Güven, herhangi bir değerli sosyal etkileşimin temel bileşenidir (Delgado-Ballester ve Luis Munuera-Alemán, 2001). Dwyer vd., (1987) iki tür ilişki vardır; ayrık işlemler ve ilişkisel alışverişler. Ayrık işlemlerin kesin bir başlangıcı, sonu ve kısa bir süresi vardır; ilişkisel alışverişler ise önceki ve sürekli etkileşimler üzerine inşa edilir ve uzun bir süreye sahiptir (Dwyer, vd., 1987). İlişkisel alışverişleri ayrık işlemlerden ayıran memnuniyet değil güvendir (Delgado-Ballester ve Luis Munuera-Alemán, 2001). Faydacı doğası nedeniyle memnuniyet, kısa vadeli ve tekrarlayan işlemsel alışverişler için daha uygulanabilirdir (Hess ve Story, 2005). İlişkisel değişim gibi güven de doğada daha kalıcıdır (Chaudhuri ve Holbrook, 2001).

1980'lerin sonlarından bu yana güven, markalaşmada esas olarak ilişkisel pazarlamanın artan önemi nedeniyle önemli bir yapı haline geldi (Delgado-Ballester ve Luis Munuera- Alemán, 2001; Hess ve Story, 2005; 
Lantieri ve Chiagouris, 2009). İlişki pazarlaması Morgan ve Hunt (1994:22) "başarılı ilişkisel alışverişlerin kurulması, geliştirilmesi ver sürdürülmesine yönelik tüm pazarlama faaliyetlerine sahip olmak" şeklinde tanımlanmıştır. Markalar ve müşterileri arasındaki başarılı ilişkiler etkileşimli, bağlantılı ve süreklidir (Vargo ve Lusch, 2011). Marka güveninin başarılı marka-tüketici ilişkilerinin anahtarı olduğu yaygın olarak kabul edilmektedir (Morgan ve Hunt, 1994; Fournier, 1998; Delgado-Ballester ve Luis Munuera-Alemán, 2001).

Hiscock (2001) pazarlamanın nihai amacı, marka ile tüketici arasında güçlü bir bağ oluşturmakta ve güven bu bağlı güçlendirmenin anahtarıdır. Ayrıca güven ile tüketici-marka ilişkileri arasında ters nedensellik vardır; bir ilişkide marka güveninin varlığı, bunun anlamını derinleştirir (Delgado- Ballester ve Luis MunueraAlemán, 2001; Hiscock, 2001). Napoli vd., (2014) marka özgünlügünün ve marka güveninin kavramsal olarak benzer, ancak yine de birbirinden farklı olduğunu iddia etmektedir. Marka güveni, iki boyuta sahip olarak kavramsallaştırılır; marka niyetleri ve marka güvenilirliği (Delgado-Ballester, 2004). Güven, algılanan riskten gelişir; tüketiciler, bir satın alma kararı konusunda kararsız veya güvensiz hissettiklerinde güvenilir markalar ararlar (Doney ve Cannon, 1997; Delgado-Ballester ve Luis Munuera-Alemán, 2001). Özgünlüğün bu tüketici belirsizliğini hafiflettiğini ve güveni yeniden inşa etmek isteyen markalar için mükemmel bir çözüm olduğu bulunmuştur (Bruhn vd., 2012; Eggers vd., 2013). Özgün markalar, sözlerini yerine getirmeye kararlıdır ve tüketiciler, gerçekleştireceğine inandıkları markalara daha fazla güvenmektedir (Bruhn vd., 2012; Eggers vd., 2013; Napoli vd., 2014; Morhart vd., 2015; Portal vd., 2019).

Chaudhuri ve Holbrook (2001) marka güvenini, tüketicinin yalnızca markanın sözünü yerine getirme yeteneğine güvenme isteği olarak tanımlamaktadır. Delgado- Ballester ve Luis Munuera-Alemán, (2001) bunu desteklemişlerdir ve marka güveninin yalnızca bir ayrı boyutu olduğunu bulmuşlardır; marka güvenilirliği. Marka niyetlerinin (bütünlügün) tüketicileri daha güvende hissetmelerine yol açan, ancak mutlaka güven oluşturmayan soyut bir marka niteliği olduğuna inanılmaktaydı (Delgado- Ballester ve Luis MunueraAlemán, 2001). Sung ve Kim (2010) bunun tam tersini, güvenilirliğin bütünlükten geliştiğini; tüketici markanın samimi ve dürüst bir şekilde performans göstereceğine güvendiğinde, ona güvenmeye daha meyilli olduğunu belirtmiştir.

Greenberg (2014), güvenin tanımına ilişkin bir fikir birliğine varmak için yapılan bir araştırmada, güvenin bir işletmenin hem yetkin hem de sağlam niyetini ima ettiği için, hedefleri gerçekleştirebileceği inancı olduğu belirtilmiştir. Şahin vd., (2011) marka güveni ölçümlerinin marka niyetlerini ve marka güvenini dahil etmiş ancak bunu tek boyutlu olarak ölçmüştür. Delgado- Ballester, (2004) marka niyetini, tüketicinin markanın kendi çıkarları doğrultusunda hareket edeceğine inanıp inanmamasına bağlıdır ve marka güveni, tüketicinin markanın sözünü yerine getirebileceğine inanmasına bağlıdır. Tüketici, hem bilişsel hem de duygusal marka özelliklerine dayalı olarak bir markanın güvenilir olup olmadığı konusunda yargıya varacaktır.

Böylece satın alınan markaya duyulan güven, o markanın güvenilirliğinin bir kaldıracı olarak görülecek ve bu da karşılığında tüketicilerin tekrar satın alma davranışını güçlendirecektir (Şahin vd., 2011).

\section{Yöntem}

\subsection{Hipotez Geliştirme ve Araştırma Modeli}

Sung ve Kim'e göre (2010) güven, yalnızca kaliteyi sağlamak değil, bunu samimi bir şekilde yapmakla inşa edilmektedir. Bazı yazarlar, tüketicilerin bir markanın işlevsel ihtiyaçlarını karşılamasını beklediğine ve bu güvenin öncelikle nezaket ve karşılıklılığın ilave duygusal güvenden geliştiğine inanmaktadır (Ashraf vd., 2006).

Delgado-Ballester (2004), marka niyetlerinin tüketiciler üzerinde marka güvenilirliğinden daha güçlü bir etkiye sahip olduğunu, çünkü ikincisinin her zaman markanın gerçek değerlerinin doğru bir yansıması olmayabileceğini belirtmiştir. Dürüst ve samimi olarak algılanan markalar, yalnızca kalite sunan markalara göre tüketiciler tarafından güvenilme olasılığı daha yüksektir (Sung ve Kim, 2010). Marka güveni, markanın adalet ve bütünlüğü algısın bağlıdır (Morgan ve Hunt, 1994; Singh, vd., 2012). Güven, bir başkasının olumlu niyetleri olduğu ve kişinin çıkarına en uygun şekilde hareket edeceği inancına dayanan bir güven hissi olarak tanımlanmıştır (Delgado-Ballester, ve ve Luis Munuera- Alemán, 2001).

Eggers vd., (2013) yılında yaptıkları çalışmada marka özgünlüğü ile marka güveni ile küçük ve orta ölçekli işletmelerin büyümesi arasında pozitif bir ilişki olduğunu belirtmiştir. Napoli vd., (2014) marka özgünlük 


\section{A. B. Hamşığlu - İ. K. Papatya 13/3 (2021) 2042-2055}

boyutlarından inanılırlık ve marka güveni arasında pozitif bir ilişki olduğunu belirtmiştir. Schallehn vd., (2014) yaptıkları çalışmada marka özgünlüğü ve marka güveni arasında pozitif bir ilişkinin olduğunu belirtmiştir. Bu bilgiler ışı̆̆ında hipotezler şu şekilde geliştirilmiştir.

H1: Marka özgünlüğü marka güvenini pozitif yönde etkiler.

Ayrıca çalışmada marka özgünlüğü boyutlarının marka güveni üzerinde ayrı ayrı etkisine de bakılmış ve şu alt hipotezler de oluşturulmuştur.

H1a: Marka özgünlüğünün süreklilik boyutu marka güvenini pozitif yönde etkiler.

H1b: Marka özgünlüğünün orijinallik boyutu marka güvenini pozitif yönde etkiler.

H1c: Marka özgünlüğünün güvenilirlik boyutu marka güvenini pozitif yönde etkiler.

H1d: Marka özgünlüğünün doğallık boyutu marka güvenini pozitif yönde etkiler.

Hipotezleri temsil eden kavramsal model Şekil 1'de gösterilmektedir.

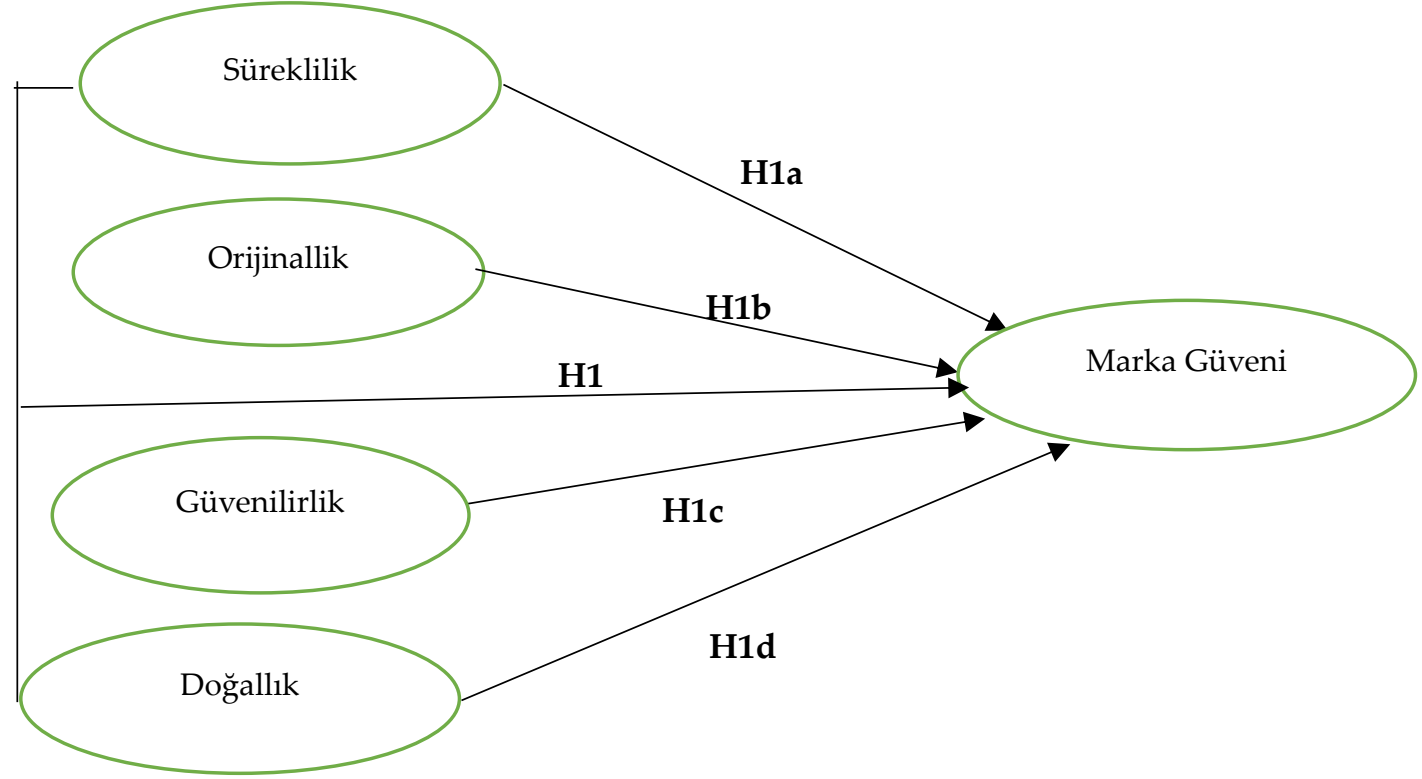

Şekil 1. Kavramsal Model: Marka Özgünlüğü Alt Boyutlarının Marka Güveni Üzerindeki Etkisi

\subsection{Evren ve Örneklem}

Bu çalışmanın ana kütlesini Türkiye'deki cep telefonu/akıllı cep telefonu kullanan 16-24 ve 25-34 yaş grubu tüketiciler oluşturmaktadır. Türkiye İstatistik Kurumu (TÜIK)'in 2018-2020 verilerine göre son üç ay (OcakMart) cep telefonu/akıllı cep telefonu kullanan 16-24 yaş arası tüketicilerin oranı 2018 yılında \%93,2, 2019 yılında \%92,4 ve 2020 (Ocak-Mart aylarında) \%94,2 olarak tespit edilmiştir. Aynı rapora göre 25-34 yaş arası tüketicilerde kullanım oranları 2018 yılında \%97,1, 2019 yılında \%97,2 ve 2020 (Ocak-Mart aylarında) \%98,0 olarak tespit edilmiştir. Çalışmada bu iki yaş aralığının seçilmesinin nedeni olarak cep telefonu kullanım oranlarının diğerlerine oranla daha yüksek oluşu ve daha genç bir nüfusu oluşturmaları olarak belirlenmiştir. Tablo 1'de cep telefonu kullanım oranları gösterilmektedir.

Buradan hareketle, bu çalışma için ana kütleden seçilecek örneklem büyüklügü için Sekaran ve Bougie (2016:263-264) da belirli bir popülasyon için örneklem hesaplama tablosuna göre 1 milyon ve üzeri ana kütlenin temsil edilebileceği örneklem sayısının 384 olarak belirtmişlerdir. Bu çalışmada da örneklem büyüklüğü olarak 384 belirlenmiştir. Çalışmada zaman, maliyet açısından zorluklar nedeni ile olasılığa dayalı olmayan örnekleme tekniklerinden kolayda örnekleme yöntemi seçilmiştir. Cevaplayıcıların şu anda kullandıkları cep telefonu/akıllı cep telefonunu düşünerek soruları cevaplamaları istenmiştir.

Yeterli örneklem büyüklüğü hesaplamada önerilen bir başka yöntem ise, ele alınan değişken madde sayısının 10 katı ya da 20 katı olması gerektiği belirtilmiştir (Kline, 2011:12). PLS-SEM, karmaşık model yapıları veya daha küçük örneklem boyutları olan durumlarda daha yüksek istatistiksel güce sahip olduğu belirtilmiş ve sıklıkla da 10 katı kuralı desteklenmektedir. Çünkü PLS-SEM yönteminde örneklem yeterliliği küçüktür ve 
veriler normal dağılım göstermemektedir (Henseler vd., 2009; Hair vd., 2014:18-19;). Bu kurallar çerçevesinde hesaplama yapıldığında, 5 değişkene ait 19 madde ile 19*10=190 olarak hesaplanmıştır.

$\mathrm{Bu}$ bilgiler çerçevesinde örneklemin ana kütleyi daha üst düzeyde temsil etmesini sağlamak amaciyla belirlenen değerlerin üstünde veri elde etmek amaçlanmıştır. Dolayısıyla test edilecek örneklem büyüklüğü 500 olarak belirlenmiştir. Elde edilen 500 anket incelenmiş olup hatalı ve eksik 30 anket tasnif dışı bırakılarak 470 anket üzerinden sonuçlar değerlendirilmiştir.

Çalışmada uygulanan anket formu çeşitli online formlar ve farklı sosyal medya kanalları olmak üzere Türkiye'de ki 16-24 ve 25-34 yaş grubu cep telefonu/akıllı cep telefonu kullanıcılarına yönelik olarak online anket uygulanmıştır. Anket uygulamasına geçmeden önce Burdur Mehmet Akif Ersoy Üniversitesi Etik Komisyonundan gerekli onay alınmıştır (Araştırma Karar No: GO 2021/218).

Tablo 1. Hane Halkı Bilişim Teknolojileri (BT) Kullanım Araştırması 2018-2020 (Son Üç Ay Ocak-Mart)

\begin{tabular}{|l|c|c|c|c|c|c|c|c|c|}
\hline & \multicolumn{3}{|c|}{$\mathbf{2 0 1 8}$} & \multicolumn{3}{c|}{ 2019 } & \multicolumn{3}{c|}{2020} \\
\cline { 2 - 10 } & Toplam & Erkek & Kadın & Toplam & Erkek & Kadın & Toplam & Erkek & Kadın \\
\hline $\begin{array}{l}\text { Cep Telefonu } \\
\text { Kullananlar }\end{array}$ & 92,7 & 96,3 & 89,1 & 93,5 & 96,9 & 90,2 & 95,3 & 97,8 & 92,7 \\
\hline Yaş Grupları & & & & & & & & & \\
\hline $16-24$ & 93,2 & 96,1 & 90,2 & 92,4 & 96,4 & 88,3 & 94,2 & 96,0 & 92,4 \\
\hline $25-34$ & 97,1 & 98,9 & 95,3 & 97,2 & 98,5 & 95,9 & 98,0 & 99,0 & 97,1 \\
\hline $35-44$ & 95,9 & 98,1 & 93,7 & 96.5 & 98,7 & 94,3 & 97,6 & 99,2 & 95,9 \\
\hline $45-54$ & 92,8 & 96,6 & 89,0 & 95,1 & 98,2 & 91,9 & 96,2 & 98,7 & 93,7 \\
\hline $55-64$ & 88,5 & 94,1 & 83.1 & 89,9 & 95,3 & 84,7 & 92,8 & 96,8 & 88,9 \\
\hline $65-74$ & 76,5 & 86,1 & 68,1 & 80,2 & 87,5 & 73,9 & 86,5 & 94,3 & 79,6 \\
\hline
\end{tabular}

Kaynak: TÜİK, Hanehalkı Bilişim Teknolojileri (BT) Kullanım Araştırması, Raporu (2018-2020 Ocak-Mart)

\subsection{Veri Toplama Arac1}

Çalışmada kullanılan anket formu iki bölümden oluşmaktadır. İlk bölümde demografik sorular yer almaktadır. İkinci bölümde ise, marka özgünlüğü (süreklilik, orijinallik, güvenilirlik ve doğallık) toplam 15 soru ve marka güveni toplam 4 soru olmak üzere toplamda 19 soru ile ölçülmüştür. Anket formu hazırlanırken marka özgünlüğü Bruhn vd., (2012) ve Morhart vd., (2015) çalışmalarından yararlanılarak hazırlanmıştır. Marka güveni ise, Delgado-Ballester (2004) çalışmasından yararlanılarak oluşturulmuştur. Kullanılan tüm ölçekler, geçerliliği ve güvenilirliği ispatlanmış ölçeklerden oluşmaktadır. Bu ölçeklerin güvenilirliği Tablo 2'de gösterilmektedir.

Tablo 2. Ölçeklerin Güvenilirliği

\begin{tabular}{|l|l|l|}
\hline \multicolumn{1}{|c|}{ Yapı } & \multicolumn{1}{|c|}{ Soru ve Kaynak } & Cronbach's alpha ( $\boldsymbol{\alpha}$ ) \\
\hline $\begin{array}{l}\text { Marka Özgünlüğ̈u } \\
\text { (dört boyut) }\end{array}$ & $\begin{array}{l}\text { a) Orijinallik (Bruhn vd.,2012) } \\
\text { b) Süreklilik (Bruhn vd.,2012; Morhart vd., 2015) } \\
\text { c) Güvenilirlik (Bruhn vd.,2012; Morhart vd., 2015) } \\
\end{array}$ & $\begin{array}{l}\text { a) } \alpha=0,86>0,70 \\
\text { d) Doğallık (Morhart vd., 2015) } \alpha=0,88>0,70 \\
\text { d) } \alpha=0,89>0,70\end{array}$ \\
\hline Marka Güveni & a) Güvenilirlik (Delgado-Ballester, 2004) & a) $\alpha=0,92>0.70$ \\
\hline
\end{tabular}

Cevaplayıcıların yanıtlarını ölçmek üzere oluşturulan sorular 5'li Likert ölçeğine göre hazırlanmıştır. Ölçek, katılımcıların 1 ile 5 arasında (1 kesinlikle katılmıyorum....5 kesinlikle katılıyorum) kendilerine sunulan ifadelere uyma düzeylerini en doğru şekilde belirtecek seçeneği işaretlemeleri istenmiştir. 


\section{Bulgular}

\subsection{Demografik Bulgular}

\section{Cevaplayıcıların Özellikleri}

Çalışma kapsamında ankete katılan katılımcıların demografik özelliklerine ilişkin bilgiler Tablo 3'de gösterilmektedir.

Tablo 3. Cevaplayıcıların Demografik Özellikleri

\begin{tabular}{|c|c|c|c|c|c|c|c|c|}
\hline \multicolumn{9}{|l|}{ Cinsiyet } \\
\hline Kadın & \multicolumn{8}{|c|}{ Erkek } \\
\hline$\% 53,0(249)$ & \multicolumn{8}{|c|}{$\% 47(221)$} \\
\hline \multicolumn{9}{|l|}{ Yaş } \\
\hline$\underline{16-24}$ & \multicolumn{8}{|l|}{$25-34$} \\
\hline \%39,4 (185) & \multicolumn{8}{|c|}{$\% 60,6(285)$} \\
\hline \multicolumn{9}{|c|}{ Medeni Durum } \\
\hline Evli & \multicolumn{8}{|l|}{ Bekâr } \\
\hline \% 60,2 (283) & \multicolumn{8}{|l|}{$\% 39,8(187)$} \\
\hline \multicolumn{9}{|c|}{ Eğitim Durumu } \\
\hline Illköğretim & \multicolumn{3}{|c|}{ Ortaöğretim } & Lise & Ön lisans & $\underline{\text { Lisans }}$ & \multicolumn{2}{|c|}{$\underline{\text { Lisansüstü }}$} \\
\hline$\% 7,4(35)$ & \multicolumn{3}{|c|}{$\% 12,6(59)$} & $\% 10,9(51)$ & $\% 14,5(68)$ & $\% 44(207)$ & \multicolumn{2}{|c|}{$\% 10,6(50)$} \\
\hline \multicolumn{9}{|l|}{ Meslek } \\
\hline Öğrenci & \multicolumn{2}{|c|}{ Kamu Çalıșanı } & \multicolumn{2}{|c|}{ Özel Sektör } & Ev Hanımı & Serbest & \multicolumn{2}{|c|}{$\underline{\text { Diğer }}$} \\
\hline$\% 23,0(108)$ & \multicolumn{2}{|c|}{$\% 26,8(126)$} & \multicolumn{2}{|c|}{$\frac{\text { Çalıșanı }}{\% 18,7(88)}$} & $\% 11,9(56)$ & $\frac{\text { Meslek }}{\% 10,6(50)}$ & \multicolumn{2}{|c|}{$\% 8,9(42)$} \\
\hline \multicolumn{9}{|c|}{ Aylık Toplam Gelir (TL) } \\
\hline \multirow{2}{*}{$\frac{1500-2000 \mathrm{TL}}{\% 7,7(36)}$} & \multicolumn{3}{|c|}{$\underline{2001-2500 ~ T L}$} & $\underline{2501-3000 \mathrm{TL}}$ & \multicolumn{2}{|c|}{ 3001-3500 TL } & 3501-4000TL & 4001 TL ve Üzeri \\
\hline & $\% 6,4(3$ & & & $\% 13,6(64)$ & $\% 15$, & $(72)$ & $\% 24,7(116)$ & $\% 32,3(152)$ \\
\hline \multicolumn{9}{|c|}{ Cep Telefonu Markası } \\
\hline$\underline{\text { Samsung }}$ & iPhone & & ppo & $\underline{\text { Xiaomi }}$ & Huawei & Vestel & $\underline{\text { LG }}$ & Diğer \\
\hline$\% 20,2(95)$ & $\% 23,6(111)$ & $\% 10$, & $6(50)$ & $\% 8,3(39)$ & $\% 11,1(52)$ & $\% 8,7(41)$ & $\% 8,9(42)$ & $\% 8,5(40)$ \\
\hline
\end{tabular}

\subsection{Ortak Yöntem Sapma Sorun Analizi}

Çoğu araştırmacı, ortak yöntem varyansının (yani ölçümlerin temsil ettiği yapılardan ziyade ölçüm yöntemine atfedilen varyansın) davranışsal araştırmalarda potansiyel bir sorun olduğu konusunda hem fikirlerdir. Yöntem önyargıların bir sonucudur çünkü bunlar, ölçüm hatasının ana kaynaklarından biridir. Ölçüm hataları, ölçümler arasındaki ilişkilerle ilgili sonuçların geçerliliğini tehdit eder ve hem rastgele hem de sistematik bir bileşene sahip olduğu yaygın olarak kabul edilmektedir. Tek bir soru formunda bağımlı ve bağımsız değişkenlerin aynı anda ölçülmesi ölçüm hatalarına ve ortak yöntem sorununa yol açtığı yapılan çalışmalarla belirtilmiştir (Bagozzi vd., 1991; Podsakoff vd., 2003; Fuller vd., 2016). Bu çalışmada da, marka özgünlüğü ve marka güveni değişkenlerine ilişkin soruların tek bir soru formunda ve aynı cevaplayıcılar tarafından aynı anda değerlendirilmesinin istenmesi nedeni ile ortak yöntem sapma sorun ihtimali bulunmaktadır.

Bu sorunun olup olmadığının ve bu ihtimalin ortadan kaldırılmasına ilişkin olarak yazında kabul edilen ve en yaygın yöntem olan Harman'ın tek faktör analiz yöntemi kullanılmıştır (Podsakoff vd., 2003:889). Çalışmada değişkenlerin tek boyut altında açılanan varyansın oranının \%43,365 olduğu sonucuna ulaşılmıştır. Elde edilen bu oran Podsakoff ve Organ (1986) yılında yapmış olduğu çalışmada önermiş olduğu \%50'nin altında olduğu görülmüştür. Yine benzer bir çalışmada Fuller vd., (2016) yılında yaptıkları çalışmada önermiş oldukları \%70 değerinin çok altında olduğu görülmüştür. Dolayısıyla bu sonuç çalışmada ortak yöntem sapma sorununun olmadığını göstermektedir. 


\section{3. Ölçüm Modeli}

Çalışmada oluşturulan modeli test etmek ve sonuçları oluşturulan hipotezlere göre değerlendirmek için SmartPLS 3.0 ile kısmi en küçük kareler yol modellemesi kullanılmıştır. Modelin yeterliliğinin analizine başlamak için, maddelerin bireysel bir değerlendirilmesi yapılmıştır. Tüm standartlaştırılmış faktör yükleri 0,50'den büyüktür ve yakınsak geçerliliğini sağlamaktadır (Bagozzi ve Yi, 1988; Hair, vd., 2011). Cronbach Alfa değerlerinin istenen değeri olan 0,70'in üzerinde olması ölçeklerin güvenilir olduğunu ve kullanılan ölçümlerin kapsam geçerliliğine sahip olduğunu göstermektedir. (Hair, vd., 2009).

Her bir yapı için bileşik güvenilirliğe (CR) bakılmış ve tüm yapılarda CR değerleri 0.70 değerinin üstünde olduğu görülmüştür (Bagozzi ve Yi, 1988). Ayrıca, ortalama varyans değerlerine (AVE) de bakılmıştır. Bu değerler Fornell ve Larcker (1981) de önerdiği 0,50 referans değerinin üstünde değerler aldığı görülmektedir (Chin, 2010). Dolayısıyla yakınsaklık geçerlilik şartı sağlanmıştır. Yapılan analizlere ilişkin tüm sonuçlar Tablo 4 'de gösterilmektedir.

Tablo 4. Faktör Analizi Sonuçları

\begin{tabular}{|c|c|c|c|c|}
\hline Ölçümler & Yükler & Alfa & $\mathrm{CR}$ & AVE \\
\hline Süreklilik & & 0,88 & 0,82 & 0,81 \\
\hline SUR 1:Bu cep telefonu markasının zaman içerisinde tutarlı olduğunu düşünüyorum & 0,84 & & & \\
\hline SUR 2: Bu cep telefonu markası süreklilik sunmaktadır & 0,81 & & & \\
\hline SUR 3: Bu cep telefonu markası izlediği bir görüşü vardır & 0,78 & & & \\
\hline SUR 4: Bu cep telefonu markası kendi ilkelerine sadık kalıyor & 0,74 & & & \\
\hline Orijinallik & & 0,86 & 0,85 & 0,83 \\
\hline ORJ 1: Bu cep telefonu markası diğer tüm markalardan farklıdır & 0,88 & & & \\
\hline ORJ 2: Bu cep telefonu markası diğer markalardan ayrılmaktadır & 0,77 & & & \\
\hline ORJ 3: Bu cep telefonu markasının benzersiz olduğunu düşünüyorum & 0,75 & & & \\
\hline ORJ 4: Bu cep telefonu markası kendisini diğer markalardan açıkça ayırır & 0,72 & & & \\
\hline Güvenilirlik & & 0,83 & 0,80 & 0,86 \\
\hline GUV 1: Bu cep telefonu markasının vaatleri inandırıcıdır & 0,84 & & & \\
\hline GUV 2: Bu cep telefonu markası vaat ettiğini yerine getirir & 0,86 & & & \\
\hline GUV 3: Bu cep telefonu markasının vaatleri inandırıcıdır & 0,88 & & & \\
\hline $\begin{array}{l}\text { GUV 4: Bu cep telefonu markasıyla ilgili tecrübelerim bana verdiği sözleri tuttuğunu } \\
\text { göstermektedir }\end{array}$ & 0,89 & & & \\
\hline Doğallık & & 0,89 & 0,83 & 0,90 \\
\hline DOG 1: Bu cep telefonu markası yapay görünmemektedir & 0,77 & & & \\
\hline DOG 2: Bu cep telefonu markası doğal olduğu izlenimi vermektedir & 0,79 & & & \\
\hline DOG 3: Bu cep telefonu markası özgün bir izlenim vermektedir & 0,75 & & & \\
\hline Marka Güveni & & 0,92 & 0,90 & 0,91 \\
\hline MGUV 1: Bu cep telefonu markasına güven duymaktayım & 0,84 & & & \\
\hline MGUV2: Bu cep telefonu markası beni hiçbir zaman hayal kırıklığına uğratmaz & 0,87 & & & \\
\hline MGUV 3: Bu cep telefonu markası beklentilerimi karşılamaktadır & 0,90 & & & \\
\hline MGUV 4: Bu cep telefonu markası memnuniyeti garanti eder & 0,89 & & & \\
\hline
\end{tabular}

Ayırma geçerliliği için ise AVE değerleri ile kare korelasyon değerleri karşılaştırılarak değerlendirilmiştir. Fornell ve Larcker (1981) ayırt edici geçerliliğin var olabilmesi için AVE'nin karekökünün yapılar arasındaki korelasyonlardan daha büyük olması gerektiğini belirtmiştir. 
A. B. Hamşığlu - İ. K. Papatya 13/3 (2021) 2042-2055

Tablo 5. Yapılar Arası Korelasyon ve Ayrışma Geçerlilik Sonuçları

\begin{tabular}{|l|c|c|c|c|c|}
\hline Değişkenler & Süreklilik & Orijinallik & Güvenilirlik & Doğallık & Marka Güveni \\
\hline Süreklilik & $\mathbf{0 , 9 0}$ & & & & \\
\hline Orijinallik & 0,64 & $\mathbf{0 , 9 1}$ & & & \\
\hline Güvenilirlik & 0,75 & 0,66 & $\mathbf{0 , 9 3}$ & & \\
\hline Doğallık & 0,61 & 0,69 & 0,73 & $\mathbf{0 , 9 5}$ & \\
\hline Marka Güvenilirliği & 0,73 & 0,76 & 0,81 & 0,83 & $\mathbf{0 , 9 5}$ \\
\hline
\end{tabular}

\section{*Diagonel değerler AVE'nin karekök değerlerini belirtmektedir.}

Ayırma analizi sonuçları Tablo 5’de gösterildiği gibi Fornell ve Larcker (1981) de önerdiği şart karşılanmış ve ayırma geçerliliği sağlanmıştır.

Çoklu doğrusallık probleminin olup olmadığı ise, Varyans Inflation Factor (VIF) istatistikleri kullanılarak değerlendirilmiştir. Referans değerleri içinde Hair vd. (2011) de önermiş olduğu VIF değerlerinin ise 5'ten küçük ve tolerans değerlerinin 0.20 'den büyük olması şartı aranmıştır. Tablo 6'da Modele ait VIF değerleri gösterilmektedir.

Tablo 6. Modele Ait VIF Analizi Sonuçları

\begin{tabular}{|l|c|}
\hline Değişkenler & Marka Güveni \\
\hline Süreklilik & 2.25 \\
\hline Orijinallik & 2,78 \\
\hline Güvenilirlik & 1,49 \\
\hline Doğallık & 1,87 \\
\hline
\end{tabular}

Modele ait VIF değerleri Hair vd. (2011) de belirtmiş olduğu 5’ten küçük olma şartını sağlamaktadır. Böylece modele ait eş doğrusallık sorunun olmadığı görülmektedir.

\subsection{Hipotez Testleri}

Çalışmada oluşturulan hipotezleri test etmek için modelin değerlendirilmesi aşamasına geçilmektedir. Bunun içinde, yol katsayılarına (Path Coefficients) ve determinasyon katsayısına bakılarak değerlendirilme yapılmıştır. Marka özgünlüğünün marka güveni üzerindeki etkilerini belirleyen ilişkiler Tablo 7 'de gösterilmektedir.

Tablo 7. Hipotez Testi Sonuçları

\begin{tabular}{|l|c|c|c|c|}
\hline \multicolumn{1}{|c|}{ İlişkiler } & Hipotezler & $\beta$ & t-değeri & Desteklendi/Desteklenmedi \\
\hline Marka Özgünlü̆̆̈ü $\rightarrow$ Marka Güveni & H1 & 0,824 & 6,14 & Desteklendi \\
\hline Süreklilik $\rightarrow$ Marka Güveni & H1a & 0,688 & 3,54 & Desteklendi \\
\hline Orijinallik $\rightarrow$ Marka Güveni & H1b & 0,744 & 4,68 & Desteklendi \\
\hline Güvenilirlik $\rightarrow$ Marka Güveni & H1c & 0,760 & 2,84 & Desteklendi \\
\hline Doğallık $\rightarrow$ Marka Güveni & H1d & 0,721 & 2,57 & Desteklendi \\
\hline
\end{tabular}

Ayrıca model değerlendirmede determinasyon katsayısına $\left(\mathrm{R}^{2}\right)$ bakılmıştır. Çalışmada marka güveni $\mathrm{R}^{2}$ değeri 0.73 olarak tespit edilmiştir. PLS sonucuna göre elde edilen sonuçlar Şekil 2' de gösterilmiştir. 


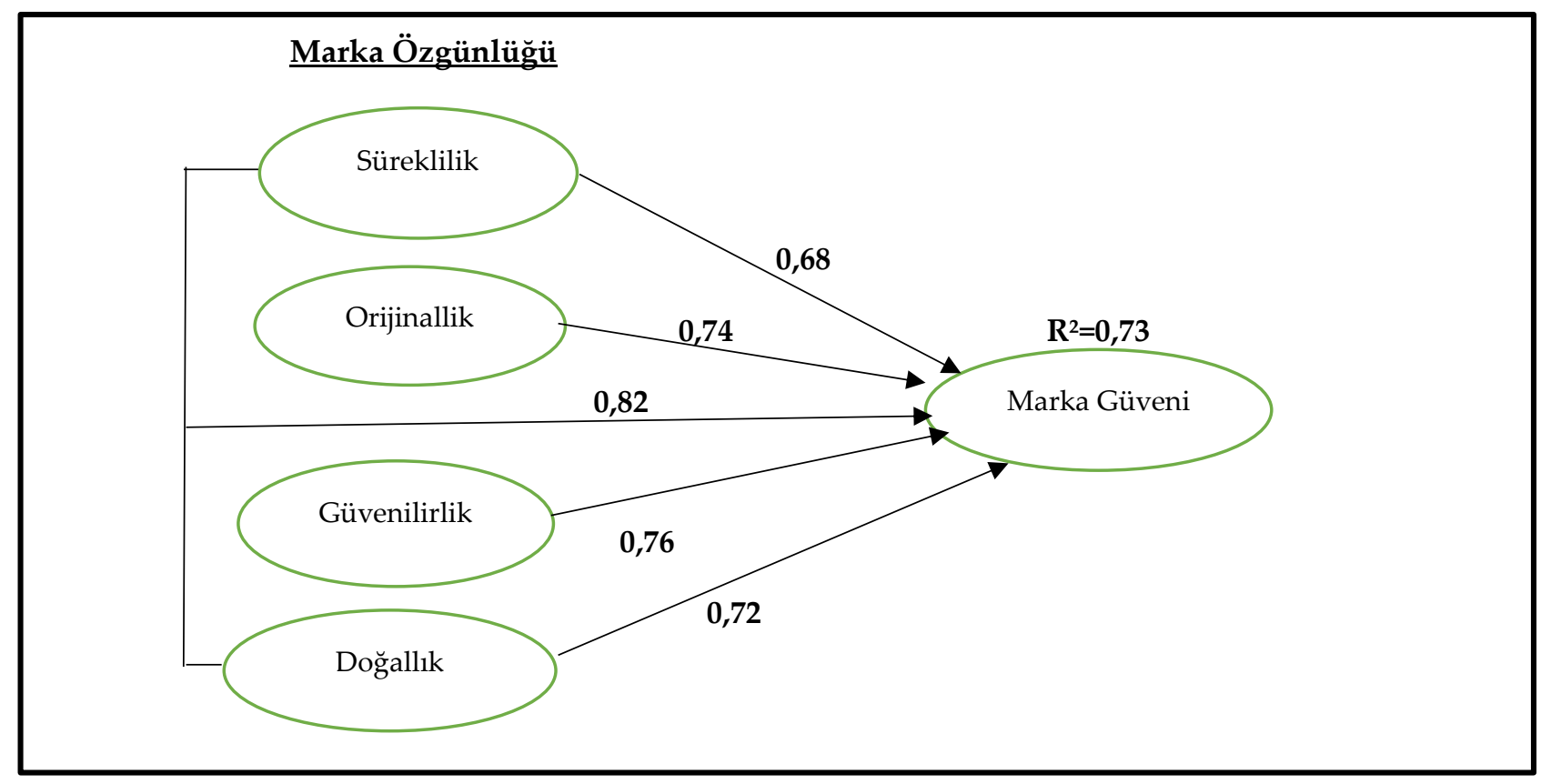

Şekil 2. PLS Sonuçları

Çalışma hipotezlerine ilişkin elde edilen bulgular şu şekildedir:

Marka özgünlüğü marka güvenini pozitif yönde etkiler. Şeklinde kurulan hipotez $\left(\beta=0,82, \mathrm{t}=6,14^{* *}, \mathrm{p}=0,001\right)$ pozitif olarak etkilediği görülmüş ve dolayısıyla oluşturulan H1 hipotezini desteklemiştir.

Marka özgünlüğünün süreklilik boyutu marka güvenini pozitif yönde etkiler. Şeklinde kurulan hipotez $\left(\beta=0,68, t=3,54^{* *}, \quad p=0,001\right)$ pozitif olarak etkilediği görülmüş ve dolayısıyla oluşturulan H1a hipotezini desteklemiştir.

Orijinallik boyutu marka güvenini pozitif yönde etkiler. Şeklinde kurulan hipotez $\left(\beta=0,74, t=4,68^{* *}, \mathrm{p}=0,001\right)$ pozitif olarak etkilediği görülmüş ve dolayısıyla oluşturulan H1b hipotezini desteklemiştir.

Güvenilirlik boyutu marka güvenini pozitif yönde etkiler. Şeklinde kurulan hipotez $\left(\beta=0,76, t=2,84^{* *}, p=0,001\right)$ pozitif olarak etkilediği görülmüş ve dolayısıyla oluşturulan H1c hipotezini desteklemiştir.

Doğallık boyutu marka güvenini pozitif yönde etkiler. Şeklinde kurulan hipotez $\left(\beta=0,72, t=2,57^{* *}, p=0,001\right)$ pozitif olarak etkilediği görülmüş ve dolayısıyla oluşturulan H1d hipotezini desteklemiştir.

\section{Sonuç ve Tartışma}

Bu araştırmanın ilk amacı marka özgünlügünün marka güveni üzerindeki etkilerini incelemekti. İkinci olarak, marka özgünlük boyutlarının marka güveni üzerinde olumlu bir etkisinin olup olmadığını belirlemekti. Marka özgünlüğü boyutları süreklilik, orijinallik, doğallık ve güvenilirlik markaları yaratmada neredeyse eşit derecede önemlidir. Marka özgünlügünün marka güveni üzerinde doğrudan bir etkisi vardır. Başarılı markalar, özgün olarak algılanan ve insana benzer özellikler sergileyen markalardır. Kendilerine ve hizmet ettikleri müşterilere sadıktırlar. Değerlerine bağlıdırlar, sözlerini yerine getirirler ve sonuç olarak müşterileri ile anlamlı ilişkiler geliştirirler. Bu çalışmadan elde edilen sonuçlar yazında yapılan çalışmalarla tutarlılık göstermektedir. Yıldız ve Kırmızıbiberin (2020) yılında yaptıkları çalışmada marka özgünlüğü boyutlarının (süreklilik, orijinallik ve güvenilirlik) marka güveni üzerinde pozitif ve anlamlı bir etkisinin olduğu tespit edilmiş ve sadece doğallık boyutunda anlamlı bir etki bulunamamıştır. Elde edilen bu sonuç ile çalışma sonucu farklılık göstermektedir. Arıkan ve Telci (2014) yılında yaptıkları çalışmada ise, marka özgünlügünün marka güvenini pozitif yönde etkilediği belirlenmiştir.

Eggers vd., (2013) yılında yaptıkları marka özgünlügünün marka güveni ve KOBİ'lerin büyümesi üzerine etkisi adlı çalışmada da marka özgünlügünün marka güveni üzerinde pozitif etkilerinin olduğu ortaya 
konmuştur. Schallehn (2014), Moulard (2016) ve Portal vd., (2019) da yapmış oldukları çalışmalarda marka özgünlüğünün marka güveni üzerinde pozitif etkilerinin olduğu tespit etmişlerdir.

Elde edilen bu bulgular, yöneticiler için önemli çıkarımları vardır. Başarılı olmak için, tüketicilerin markalarına güvenmeleri gerekiyor ve onlar tarafından bu şekilde görülen markaların, olmayanlara göre daha başarılı olması muhtemeldir. Üst düzey yöneticiler, marka için planlama aşamasından itibaren net bir vizyona sahip olmalı ve dürüstlük, güvenilirlik, etik, samimiyet ve güvenliği içeren kurumsal değerler geliştirmelidir.

Markanın özgünlüğünü artırmak için işletmeler, tüm iç ve dış iletişim kaynaklarını kullanarak birleşik bir marka algısı yaratmayı da hedeflemelidir. Bu, tüm iletişim araçları aracılığıyla marka adının, logosunun ve sloganın kalıcı bir sunumunu ifade edecektir.

Kurumsal sosyal sorumluluk programları da önemlidir, çünkü otantik markaların müşterileri kadar topluluklarına da bağlllık göstermeleri gerekir. Marka yöneticileri, zaman içinde güvenilirlik ve süreklilik oluşturan marka stratejilerine sahip olmalıdırlar. Ürün ve iletişim stratejilerine kalite, tutarlılık, özgünlük ve uygunluk dâhil edilmelidir. Çalışan davranışı markanın sıcaklığını ve yetkinliğini güçlendirmelidir. Böylece tüm çalışanlar (üst yönetim dâhil) samimi arkadaş canlısı ve yetenekli görünmelidir. Tüm çalışanlar marka değerlerini anlamalı ve değerlerle yaşamalıdırlar. Bu, iç marka yönetimi programlarının çalışanlara markayı yaşamaları ve marka vaadini yerine getirmede rollerini oynamaları için marka bilgisi sağlamasını gerektirebilir. Tüketiciler markaya güveneceklerse marka vaadini tutması gerekmektedir.

$\mathrm{Bu}$ araştırma, cep telefonu kullanıcıları üzerine gerçekleştirilmiştir. Gelecekte yapılacak çalışmalarda belirli bir cep telefonu markası ve/veya farklı markalar üzerine ve farklı yaş gruplarında yapılarak elde edilen bulgular karşılaştırılabilir.

Çalışmada kolayda örnekleme yönteminin kullanılması da sonuçların genellemesinin zorlaştırmakta ve yine çalışmanın cep telefonu markaları üzerine yönelik olması çalışmanın bir sınırını oluşturmaktadır. Yapılacak diğer çalışmalarda farklı sektörlerin ve değişkenlerin seçimi önerilmektedir.

\section{KAYNAKÇA}

Akbar, M. M., and Wymer, W. (2016). Refining the conceptualization of Brand Authenticity. Journal of Brand Management, 24(1), 14-32.

Alexander, N. (2009). Brand authentication: Creating and maintaining brand auras. European Journal of Marketing, 43(3/4), 551-562.

Arıkan, E. ve Telci, E. E. (2014). Marka Özgünlüğü, Marka Güveni ve Müşteri Satın Alma Davranışı. Gaziantep Üniversitesi İktisadi ve İdari Bilimler Fakültesi 19. Ulusal Pazarlama Kongresi Bildiri Kitabı, 523-532.

Ashraf, N., Bohnet, I., and Piankov, N. (2006). Decomposing trust and trustworthiness. Experimental Economics, 9(3), 193-208.

Bagozzi, R. P., and Yi, Y. (1991). Multitrait-multimethod matrices in consumer research. Journal of Consumer Research, 17, 426-439.

Bagozzi, R. P., Yi, Y., and Phillips, L. W. (1991). Assessing construct validity in organizational research. Administrative Science Quarterly, 36, 421-458.

Bagozzi, R., and Yi, Y. (1988). On the evaluation of structural equation models. Journal of the Academy of Marketing Science, 16(1), 74-94.

Beverland, M. (2005a). Crafting brand authenticity: The case of luxury wines. Journal of Management Studies, 42(5), 1003-1029.

Beverland, M. (2005b). Brand management and the challenge of authenticity. Journal of Product $\mathcal{E}$ Brand Management, 14(7), 460-461.

Beverland, M., and Farrelly, F. (2010). The quest for authenticity in consumption: Consumers' purposive choice of authentic cues to shape experienced outcomes. Journal of Consumer Research, 36(5), 838-856. 


\section{A. B. Hamşığlu - İ. K. Papatya 13/3 (2021) 2042-2055}

Brown, S. (2010). Where the wild brands are: Some thoughts on anthropomorphic marketing. The Marketing Review, 10(3), 209-224.

Bruhn, M., Schoenmüller, V., Schafer, D., and Heinrich, D. (2012). Brand authenticity: Towards a deeper understanding of its conceptualization and measurement. Advances in Consumer Research, 40, 567-576.

Burnett, J., and Hutton, R. B. (2007). New consumers need new brands. Journal of Product \& Brand Management, 16(5), 342-347.

Chaudhuri, A., and Holbrook, M. B. (2001). The chain of effects from brand trust and brand affect to brand performance: the role of brand loyalty. Journal of Marketing, 65(2), 81-93.

Chin, W. (2010). How to write up and report PLS analyses. [içinde], (ss.655-690),[Ed.V. E. Vinzi, W. W. Chin, J. Henseler, and H. Wang], Handbook of partial least squares: Concepts, methods and applications. Springer Heidelberg Dordrecht London New York.

Delgado-Ballester, E. (2004). Applicability of a brand trust scale across product categories: A multigroup invariance analysis. European Journal of Marketing, 38(5/6), 573-592.

Delgado-Ballester, E., and Luis Munuera- Alemán, J. (2001). Brand trust in the context of consumer loyalty. European Journal of Marketing, 35(11/12), 1238-1258.

Doney, P. M., and Cannon, J. P. (1997). An examination of the nature of trust in buyer-seller relationships. Journal of Marketing, 61(2), 35-51.

Dowell, D., Heffernan, T., and Morrison, M. (2013). Trust formation at the growth stage of a business tobusiness relationship: A qualitative investigation. Qualitative Market Research: An International Journal, 16(4), 436-451.

Dwyer, F. R., Schurr, P. H., and Oh, S. (1987). Developing buyer-seller relationships. Journal of Marketing, 51(2), $11-27$.

Eggers, F., O'Dwyer, M., Kraus, S., Vallaster, C., and Güldenberg, S. (2013). The impact of brand authenticity on brand trust and SME growth: A CEO perspective. Journal of World Business, 48(3), 340-348.

Fornell C., and Lacker, F., D., (1981). Evaluating structural equation models with unobservable variables and measurement error. Journal of Marketing Research, 18 (1), 39-50.

Fournier, S. (1998). Consumers and their brands: Developing relationship theory in consumer research. Journal of Consumer Research, 24(4), 343-353.

Fuller, C. M., Simmering, M. J., Atinc, G., Atinc, Y., and Babin, B. J. (2016). Common methods variance detection in business research. Journal of Business Research, 69(8), 3192-3198.

Gilmore, J. H., and Pine, J. (2007). Authenticity: What consumers really want. Boston, MA: Harvard Business School Press.

Greenberg, M. R. (2014). Energy policy and research: The underappreciation of trust. Energy Research \& Social Science, 1(2014), 152-160.

Guevremont, A., and Grohmann, B. (2017). Does brand authenticity alleviate the effect of brand scandals? Journal of Brand Management, 25 (4), 322-336.

Hair J., E., Ringle C., M., and Sarstedt M., (2011). PLS-SEM: Indeed a silver bullet. Journal of Marketing Theory and Practice, 19(2), 139-151.

Hair J.,F., Hult G.,T., Ringle C.,M., and Sarstedt M., (2014). A Primer on Partial Least Squares Structural Equation Modeling (PLS-SEM), Sage Publication, Thousand Oaks, California.

Hair J.,F., Sarstedt M., Pieper, T., M., and ., Ringle C.,M, (2009). The Use of Partial Least Squares Structural Equation Modelling İn Strategic Management Research: A Review of Past Practices and Recemmendations for Future Applications. Long Range Planning, 45, 320-340.

Henseler J., Ringle C.,M and Sinkovics, R.,R., (2009). The Use of Partial Least Squares Path Modelling in International Marketing. Advances in International Marketing, 20, 277-319. 
A. B. Hamşığlu - İ. K. Papatya 13/3 (2021) 2042-2055

Hess, J., and Story, J. (2005). Trust-based commitment: Multidimensional consumer-brand relationships. Journal of Consumer Marketing, 22(6), 313-322.

Hiscock, J. (2001). Most trusted brands. Marketing, 1(March), 32-33.

Hobbs, J. E., and Goddard, E. (2015). Consumers and trust. Food Policy, 52, 71-74.

Hon, L. C., and Grunig, J. E. (1999). Guidelines for measuring relationships in public relations. Gaines, FL:Institute for public relations

Kline, R.B. (2011). Principles and Practice of Structural Equation Modeling, (Third Edition), New York: Guilford Press.

Lantieri, T., and Chiagouris, L. (2009). Brand trust in an age without trust: Expert opinions. Journal of Consumer Marketing, 26(2), 78-86.

Malone, C., and Fiske, S. T. (2013). The human brand: How we relate to people, products, and companies. New York, NY: John Wiley \& Sons Marketing, 27(7), 639-661.

McAllister, D. J. (1995). Affect-and cognition-based trust as foundations for interpersonal cooperation in organizations. Academy of Management Journal, 38(1), 24-59.

Molleda, J.-C. (2010). Authenticity and the construct's dimensions in public relations and communication research. Journal of Communication Management, 14(3), 223-236.

Molleda, J.-C., and Jain, R. (2013). Testing a perceived authenticity index with triangulation research: The case of Xcaret in Mexico. International Journal of Strategic Communication, 7(1), 1-20.

Morgan, R. M., and Hunt, S. D. (1994). The commitment-trust theory of relationship marketing. Journal of Marketing, 58(3), 20-38.

Morhart, F., Malär, L., Guèvremont, A., Girardin, F., and Grohmann, B. (2015). Brand authenticity: An integrative framework and measurement scale. Journal of Consumer Psychology, 25(2), 200-218.

Moulard, J. G., Raggio, R. D. and Folse, J. A. G. (2016). Brand Authenticity: Testing the Antecedents and Outcomes of Brand Management's Passion for its Products, Psychology and Marketing, 33/6, 421-436.

Napoli, J., Dickinson, S. J., Beverland, M. B., and Farrelly, F. (2014). Measuring consumer-based brand authenticity. Journal of Business Research, 67(6), 1090-1098.

Napoli, J., Dickinson-Delaporte, S. J., Beverland, M. B., and Farrelly, F. (2016). The brand authenticity continuum: Strategic approaches for building value. Journal of Marketing Management, 32(13-14), 12011229.

Pace, S. (2015). Can a commercially oriented brand be authentic? A preliminary study of the effects of a probusiness attitude on consumer-based brand authenticity. Journal of Applied Business Research, 31(3), 11671178.

Podsakoff, P. M. and Organ, D. W. (1986). Self-reports in organizational research: Problems and prospects. Journal of Management, 12 (4), 531-544.

Podsakoff, P. M., MacKenzie, S. B., Lee, J. Y. and Podsakoff, N. P. (2003). Common method biases in behavioral research: a critical review of the literature and recommended remedies, Journal of Applied Psychology, 88 (5), 879-903.

Portal, S., Abratt, R., and Bendixen, M., (2019). The Role of Brand Authenticity in Developing Brand Trust. Journal of Strategic Marketing, 27 (8), 714-729.

Rousseau, D. M., Sitkin, S. B., Burt, R. S., and Camerer, C. (1998). Not so different after all: A cross discipline view of trust. Academy of Management Review, 23(3), 393-404.

Şahin, A., Zehir, C., and Kitapçı, H. (2011). The effects of brand experiences, trust and satisfaction on building brand loyalty; an empirical research on global brands. Procedia - Social and Behavioral Sciences, 24(2011), 1288-1301. 
A. B. Hamşığlu - İ. K. Papatya 13/3 (2021) 2042-2055

Schallehn, M., Burmann, C., and Riley, N. (2014). Brand authenticity: Model development and empirical testing. Journal of Product \& Brand Management, 23(3), 192-199.

Sekaran, U. and Bougie, R. (2016). Research Methods for Business: A Skill Building Approach. (Seventh Edition). West Sussex, John Wiley \& Sons.

Shen, H., and Kim, J.-N. (2012). The authentic enterprise: Another buzz word, or a true driver of quality relationships? Journal of Public Relations Research, 24(4), 371-389.

Singh, J. J., Iglesias, O., and Batista-Foguet, J. M. (2012). Does having an ethical brand matter? The influence of consumer perceived ethicality on trust, affect and loyalty. Journal of Business Ethics, 111(4), 541- 549.

Sung, Y., and Kim, J. (2010). Effects of brand personality on brand trust and brand affect. Psychology $\mathcal{E}$ Marketing, 27(7), 639-661.

Vann, E. F. (2006). The Limits of Authenticity in Vietnamese Consumer Markets. American Anthropologist, 108(2), 286-296.

Vargo, S. L.,and Lusch, R. F. (2011). It's all B2B... and beyond: Toward a systems perspective of the market. Industrial Marketing Management, 40(2), 181-187.

Yıldız, S., ve Kırmızıbiber, A., (2020). Marka Özgünlügü: Cep Telefonu Kullanıcıları Üzerine Bir Araştırma. Pamukkale Üniversitesi, Sosyal Bilimler Enstitüsü Dergisi, 40, (Temmuz), 37-52. 